\title{
The Role of Linguistic Devices in Representing Ethnicity in The Kite Runner
}

\author{
Muhammad Asghar Malik (Corresponding author) \\ Assistant Professor, English Department \\ Govt. Postgraduate College Samanabad, Faisalabad, Pakistan \\ Tel: 923-336-064-242 E-mail: ma291b@gmail.com \\ Syed Kazim Shah \\ Department of Applied Linguistics \\ G C University Faisalabad, Pakistan \\ E-mail: kazimkazmi@gmail.com

\begin{abstract}
Rashid Mahmood
Department of Applied Linguistics

G C University Faisalabad, Pakistan

E-mail: ch.raashidmahmood@gmail.com
\end{abstract}

$\begin{array}{ll}\text { Received: December 18, } 2012 & \text { Accepted: January 5, } 2013 \text { Published: February 28, } 2013 \\ \text { doi:10.5296/ijl.v5i1.3303 } & \text { URL: http://dx.doi.org/10.5296/ijl.v5i1.3303 }\end{array}$

\begin{abstract}
The purpose of the present research is to analyse the role of the linguistic devices which the writer has used to represent ethnicity in the novel, The Kite Runner. The present research was conducted primarily in accordance with the analytic tools of CDA suggested by Huckin. McGregor has also used them in his research. This is mainly a qualitative research and the quantitative methodology of Corpus linguistics has also been used as a supplement. The results of the research reveal that the writer has employed linguistic manipulation as a powerful instrument to represent ethnicity. He has used specific linguistic devices, like foregrounding, backgrounding, presupposition, omission, framing and first person narrative,
\end{abstract}




\section{Macrothink}

International Journal of Linguistics

ISSN $1948-5425$ 2013, Vol. 5, No. 1

to influence the readers to make them accept ideological message contained in the text. This study will help in developing critical thinking of the readers by enabling them to decode text manipulation.

Keywords: Linguistics devices, Critical discourse analysis, Text manipulation, Ethnicity, Taliban, Hazara 


\section{Introduction}

The Kite Runner was published in the post-9/11 environment. Since the American declaration of war on terrorism, people have been taking much interest in reading topics like Islam, terrorism, and conflict in Afghanistan. A lot of books, articles, magazines, and documentaries were published in America on Taliban, Osama Bin Laden, and women's rights in Afghanistan. But, the works of fiction in English on Afghanistan were not published until 2003.

In America, Khaled Hosseini is the first writer who published English fiction on Afghanistan. He wonderfully depicts the political and the social situation of Afghanistan in the novel, The Kite Runner. It foregrounds a touching and unforgettable story of the relationship between two boys, Amir and Hassan, who belong to differing social class and ethnic backgrounds. The ethnic and social distinction plays a crucial role in the plot of the novel between Sunny Pashtun \& Shi'a Hazara. The writer has used particular linguistic devices for the depiction of the culture and representation of ethnicity through the sufferings of the ethnic Hazaras. It is replete with surprising twists and turns. The novel presents a tightly and intricately woven story of dominance and oppression.

The novel, The Kite Runner, had the foremost impact on millions of people across America and abroad. It received numerous positive and negative reviews. Edwards (2009) analyzed The Kite Runner and put up the reservations of the Hazara community about the validity of the facts mentioned in the said novel. Lidyawati (2010) analyzed its main characters and described their moral values in her thesis. Luckhardt (2010) highlighted the significance of cultural education through the story of The Kite Runner. Her research is significant in understanding the society and culture presented to the readers in the novel. However, linguistic analysis of the text of the novel was the area which was yet to be explored. I analysed the linguistic devices which the writer has used to manipulate the text of the novel in favour of his objectives. Instead of describing the normative use of these linguistic devices, it was analysed how the writer actually has used them in a particular context.This study aims to use Critical Discourse Analysis for the interpretation of the text of the said novel.

Linguistic devices play a vital role in exchanging ideas between the writer and the reader in natural communication. These devices are designed to control the ebb and flow of knowledge, belief, narration, and assertion during both planned and unplanned discourse. By using analytic tools of CDA, it can be made visible the way in which literary pieces and their discourse shape the mind of the reader.

The present study provides an analytical way of learning about Afghan history and culture in the context of story. It was analyzed how the choice of specific linguistic structures influenced the readers and made them receive ideological message conveyed in the text of The Kite Runner (Zhao, 2011).

The present research has been conducted to analyze the linguistic features of the text of the novel, The Kite Runner. The data collected served to analyze the text of the novel, at macro and micro level, to answer the following research questions of the present research. 
1) How does the writer manipulate the text of the novel to represent ethnicity?

2) Which linguistic devices the writer has used to create discourse of difference in the novel?

3) What is the role of the linguistic devices in representing ethnicity in the novel?

This is mainly a qualitative research but quantitative methodology of Corpus linguistics has also been used as a supplement (Mautner, 1995). It provided a detailed analysis of the text of the novel. The data collected served to analyze the text of the novel, at macro and micro level, to answer the research questions of the present research. For Quantitative Analysis, lexicons have been used to produce Frequency Indexes. The statistically significant results of quantitative data have been used for the text interpretation in depth. This triangulation of qualitative and quantitative data have been employed to demonstrate the validity of the present research (Cohen, 2007).

Generally, a literary text has been analyzed and evaluated by applying conventional tools of stylistics and pragmatics. In the text analysis, the core assumption of CDA that makes the approach different from other approaches is that it decodes not only propositional meaning of the text but also its ideological assumptions. The writer chooses specific linguistic structures to maneuver the facts in order to make the readers accept ideological message of the text (Guerin, 2007). The present research aims at enabling the readers to detect this manipulation by using critical discourse analysis.

The present research has revealed how much the language has the potential to distort the face of truth while the reader is unaware. With the help of Huckin's (1997) analytic tools of CDA, it uncovered the ideologies working within the texts which surround us in daily life (Van Dijk, 1988). Ultimately, this study will help in developing critical thinking of the readers by enabling them to decode text manipulation. Therefore, the present study will not only develop an awareness of the linguistic devices but also a wider range of language uses in our daily lives.

This research is also an attempt to highlight the scope of Critical Discourse Analysis for the text analysis of the novel. It will help to know how CDA techniques can assist in the formulation of appropriate strategies for reading. This research will invite researchers to explore new horizons of text analysis by using agenda of CDA. It will motivate related researches, for instance, applying CDA to the texts of poetry, drama and fiction.

\section{Methodology}

In the present research, the research problem is to investigate how the linguistic devices have been employed to represent ethnicity to influence the opinion of the readers of the novel, The Kite Runner. For this purpose, Huckin's (1997) analytic tools of CDA were used for the text interpretation of the said novel. As there is no single theory or methodology of research in CDA (Wodak 2006), the insight was sought from the works of major Critical Discourse Analysts (Fairclough, 1992, 1995a, 1995b; Wodak, 2001, 2003, 2006; Van Dijk, 2005, 2006; Lakoff and Johnson, 1980). 
In the present research, Huckin's (1997) analytic tools were used for the text analysis of the said novel because of the following three reasons:

1) Huckin's (1997) analytic tools provide a framework of text analysis according to the agenda of CDA.

2) They are capable of providing data which can be used both at macro level of text analysis to reveal the 'big picture' of the representation of ethnicity and at micro level to explore the answers of the research questions regarding the role of the linguistic devices in the novel.

3) The tools can provide the data which can be used for Quantitative Analysis as well as Qualitative Analysis of the text of the novel, The Kite Runner. McGregor (2003) has also used them in his research.

\subsection{The Procedure of Research}

In the present research, by using Huckin's (1997) analytic tools of CDA, the analysis has been conducted on the following three levels:

1) Framing of text as a whole: Foregrounding \&Backgrounding, Deletion, Presupposition

2) Sentence Level: Topicalization, Deletion, Presupposition

3) Words Level - Nouns, Pronouns, Adjectives, metaphors

\section{Discussion}

The objective of the present analysis was to identify the role of linguistic devices of the text of the Khaled Hosseini's novel, The Kite Runner, in representing ethnicity. The text has been analyzed and interpreted by using Huckin's (1997) analytic tools of CDA. The data collected served to analyze the text of the novel, at macro and micro level, to answer the research questions of the present research (see 1.). At the first level, the text was analyzed as a whole and the following linguistic devices were determined and interpreted.

\subsection{Framing of Text as a Whole}

Framing is a device to restrict the meaning so as to convey a particular interpretation to the mind of the reader/listener (Lakoff, 2004). In the present research, the Framing of text of The Kite Runner has been analyzed as a whole. It has been evaluated how the content of the text has been presented and what sort of perspective the writer has taken in the novel. The analysis provided the data which have been used both at the macro level of text analysis to reveal the 'big picture' of the representation of ethnicity and at the micro level to explore the role of the linguistic devices in the novel under analysis. The writer has used the following linguistic devices for the construction of particular frames.

\subsubsection{Foregrounding and Backgrounding}

In the present research, the techniques of foregrounding and backgrounding have been analyzed to explore how the writer has used them to emphasize or de-emphasize certain 
concepts in the text under analysis. It has been found that the writer of the novel used the linguistic devices of foregrounding and backgrounding very successfully in order to highlight the issue of ethnicity. Following are some of the examples from the text of the novel under analysis:

1) The first sentence of the first paragraph of the novel is pregnant with harsh element of Pashtun-Hazara ethnicity. Amir says:

"I became what I am today at the age of twelve, on a frigid overcast day in the winter of 1975. I remember the precise moment, crouching behind a crumbling mud wall, peeking into the alley near the frozen creek."'(Ch.1)

When Amir says this, he is referring back to when his best friend Hassan was raped. These are the first two sentences of the novel and the reader can tell much about the theme of the novel by these particular words. These sentences make the reader think that the narrator has experienced a life-changing event as a child. The narrator has suffered from something that has changed his life in many ways. Reference to sexual violence against a member of one ethnic group- the Hazara- at the thematic position of the novel indicates hidden objective of the writer. He intends to highlight the frame of ethnicity in the very beginning of the novel.

2) Repetition of the same reference of sexual violence in the last sentence of the first chapter of the novel is again a successful effort of foregrounding of ethnicity:

"I thought of the life I had lived until the winter of 1975 came and changed everything. And made me what I am today."

3) The writer presents Amir and Hassan as the representatives of different sides of the same society - the rich and poor, Sunni and Shia, Pashtun and Hazara, powerful and powerless.

4) Amir accepts the domination of the powerful over the powerless by letting Assef rape Hassan. He sacrifices himself as Hassan once sacrificed himself for him, Amir redeems himself only by rescuing Sohrab. He stands up against this domination. In doing so, Amir is left with a split upper lip like Hassan's cleft lip. It is a symbol of Amir's sacrifice. It suggests the union of Afghanistan's two ethnic groups- Pashtun and Hazara.

5) Moreover, Amir, in the hospital, describes a dream in which Assef tells him, "We're the same, you and I. You nursed with him, but you're my twin" (P.307). The novelist establishes a very meaningful similarity between Amir and Assef. Amir and Assef are Pashtuns. They belong to rich, well-established families, and they share similar backgrounds. The Pashtun, Assef, raps the Hazara, Hassan, and the other Pashtun, Amir, let him do so. They represent a particular part of Afghan society- the ruling power.

6) The climax of the novel is very significant. Amir is finally able to atone for his past. It occurs in Amir's fight against Assef. It is the irony that Amir has to rescue Sohrab from the same person that raped Hassan in the past. 
The above mentioned data point out that Khaled Hosseini, in his novel, The Kite Runner, maneuvers facts by using the linguistic devices of Foregrounding \& Backgrounding. Through Amir, the writer makes the point that Afghanistan must atone for its own remorseful history of violence and discrimination. It can redeem itself through social justice and sacrifice. It is the way for Afghanistan to be good again.

\subsubsection{Deletion/ Omission}

In the present research, the technique of deletion/omission has been analyzed to explore how the writer has used to keep certain things completely out of a text. If the writer does not describe something, it often will not even enter the reader's mind. Thus, it will not subject to the reader's scrutiny. Textual analysis is not merely ideational i.e. analysis of what is represented but also of what is not (Fairclough, 1995b). The writer uses the linguistic device of deletion/omission for the depiction of certain characters with a particular objective in order to influence the mind of the readers in The Kite Runner. By doing so, he makes the reader see, through the glasses of the writer, a constructed reality. Following are some of the examples:

\subsubsection{Framing of character of Baba}

The writer has depicted the character of Baba as a noble person in general. But, he has intentionally deleted certain traits of integrity, honesty and loyalty from his personality. The writer has distorted all the Pashtun characters in one way or the other. Baba is a wealthy businessman who supports the community by creating businesses for others. He builds a new orphanage. He is also the biological father of Hassan, a secret that he never discloses. He believes that sin is a form of stealing something from one's fellow man. He does not approve the religiosity demanded by the teacher in the religion classes attended by Amir in school. He wishes that Amir should be as manly as he is. He often appears to favour Hassan. After his exile to America, he works at a gas station. After Amir and Soraya's marriage, he dies from cancer in 1987. But, with all his nobility, it is Baba who has gotten Sanaubar pregnant, making Hassan his son. Baba betrays Ali who is his closest friend of childhood, by sleeping with his wife. Amir says that it is the worst possible way to dishonour an Afghan man to have a sex with his wife. Thus, the writer has created the character of Baba in order to establish ethnicity.

\subsubsection{Framing of character of Amir}

The writer has distorted the character of Amir by omitting traits of sincerity, loyalty and integrity from his personality. Amir is a Pashtun and the narrator of the novel. As a child, Amir is interested in story writing. He was encouraged by Rahim Khan to become an author. At the age of eighteen, he and his father fled to America after the Soviet invasion in Afghanistan. Amir thinks that he is more like his father than he thought. However, Baba and Amir both share betrayal of their best friends.

Amir, in contrast to Hassan, is not ready to sacrifice anything for Hassan. He is so selfish that he plans to expel Hassan and Ali from the house by blaming them of theft.

The writer makes Amir feel as if his whole life had been 'a cycle of lies, betrayals, and 
secrets'. He finally realizes that Baba was a betrayer, liar, and secret-keeper like that of him. In this way, he realizes that the importance of his redemption is twofold. He says: "Rahim Khan had summoned be here to atone not just for my sins but for Baba's too (Ch. 19)."

Even after knowing that Hassan is his brother, Amir is not willing to go to America because his association to America is stronger than his feeling of responsibility to anyone in home, a career, and a family." He finally agrees to search Sohrab. He acknowledges his lack of loyalty to his country.

\subsubsection{Framing of character of Assef}

The writer has framed the character of Assef as an embodiment of evil by eliminating every positive trait of a human being from his personality. He is the main "Antagonist" of the novel. The writer presents Assef as the son of an Afghan father and a German mother. Ironically, he is of mixed origin and an activist of Pashtun dominance over the Hazara. As a youngster, he is a tyrant in the locality. Amir describes him as a 'sociopath'. During his childhood, Assef commits the crime of raping Hassan. He gives Amir the biography of 'Adolf Hitler' as a birthday gift. As an adult, he becomes an active member of the Taliban and commits crimes of raping and abusing Hassan's son, Sohrab.

Assef does not feel any regret for what he does. He does not keep the difference between right and wrong in view. He does not care about anyone but himself. When he hurts people he does not think he was wrong. He has no regret for anyone. He abuses Sohrab and many other children without any prick of conscience. He believes in his superiority and intends to exterminate all Hazaras. So, he is self-centered and fails to realize the feelings of others. His inhuman nature impels him to do many horrible things to others. These events have a significant impact on the emotional and social development of the society.

Assef praises Hitler and determines to eliminate the Hazara from Afghanistan. He calls Amir and Baba 'a disgrace to Afghanistan' for their favour to Hazaras. Even as a teenager, he is the supporter of extermination of the Hazara. $\mathrm{He}$ is a violent person who has no regard for emotions or suffering of others. As an adult, he joins the Taliban and joyfully slaughters Hazaras in Mazar-i-Sharif.

In Chapter Eight, Assef offers a gift to Amir. It is a biography of Hitler. In Chapter 22, he joins the Taliban, not for money but to perform his divine duty. Ever since, he sets himself 'on a mission' to get rid of those he considered undeserving of living in Afghanistan, the Hazara.

\subsubsection{Framing of character of Ali}

The writer has framed the character of Ali as a pitiable victim of atrocities of Pashtuns. By showing intensity of his disgrace, the writer intends to highlight the issue of ethnicity in Afghanistan. For this purpose, the writer eliminates the elements of honour, dignity and even physical fitness from the character of Ali. He has been presented as Baba's servant who is believed to be the father of Hassan. In his youth, Baba's father adopted him when his parents were killed in an accident. Ali had been suffering from polio before the beginning of the 
novel. It causes his right leg useless. Because of this, Ali is constantly tormented by children in the town. Finally, he is killed by a land mine in Hazarajat. The writer presents his distorted physical description: a congenital paralysis, perpetually grim faced the stone-faced, "flat-nosed", _Babalu_, or Boogeyman. Children degrade him by saying "a slant-eyed donkey". Even his wife is shown disloyal, who runs off with a band of traveling singers and dancers. She scoffs at him as: "This is a husband?" she would sneer. "I have seen old donkeys better suited to be a husband."

Thus, the writer depicts the character of Ali, the Hazara, with all negative features. Being a Hazara, he has been presented as a source of humiliation, disgrace and shame.

\subsubsection{Framing of character of Hassan}

In the novel, Hassan has been described as having a face with a harelip. The reader finally comes to know that Hassan is actually the son of Baba and Sanaubar. However, Hassan does not know this reality during his lifetime. Assef often taunts Hassan as a "flat-nosed" Hazara who does not belong to Afghanistan. In Chapter Seven, the reader regretfully witnesses Hassan's rape, to which Amir refers in Chapter One. Hassan is a very brave person, but in the case of rape, he does not show resistance. In order to secure the kite for Amir, he accepts his humiliation and submission. He gets 'the look of the lamb' in his eyes. His loyalty to Amir makes him surrender even to the terribly violent act of rape. The writer presents a vivid picture of this scene:

“Assef knelt behind Hassan, put his hands on Hassan's hips and lifted his bare buttocks. He kept one hand on Hassan's back and undid his own belt buckle with his free hand. He unzipped his jeans. Dropped his underwear. He positioned himself behind Hassan. Hassan didn't struggle. Didn't even whimper. He moved his head slightly and I caught a glimpse of his face. Saw the resignation in it. It was a look I had seen before. It was the look of the lamb." (P. 76)

The writer associates deformity with the character of Hassan throughout his life. His cleft lip is a symbol of his position in society. The young Amir openly realizes that Hassan is inferior to him because of his poverty, ethnicity, religion, and deformity. Later, the Taliban killed Hassan for his refusal to abandon Baba's house. The writer has used the character of Hassan to show the asymmetrical power relationship in the Afghan society (Fairclough, 1992, 1995a).

\subsubsection{Framing of character of Sohrab}

In the novel, Sohrab is another Hazara who has been presented as an instrument to intensify the concept of ethnicity in Afghanistan. The writer has also framed this character as a pitiable victim of atrocities of Pashtuns. Sohrab is a symbol of continuity of humiliation, oppression and suppression (ibid) which travel from generation to generation. There are wounds that leave permanent marks. Assef and the Taliban inflict on him physical and sexual abuse. Psychologically, he is extremely upset and takes bathes for long periods. He realizes that he is dirty as a result of his rape. He is so frightened of going back to an orphanage that he tries to commit suicide because of this abuse. Even after his recovery, Sohrab shows his desire to 
have his old life back. He stops talking completely. He is tortured by a feeling that he is dirty because Assef and his men have physically abused him.

\subsubsection{Technique of Presupposition}

In the present research, the linguistic device of presupposition has been analyzed to explore how the writer has used it for the construction of a particular reality (Huckin, 1997). By using this technique, the writer intends to influence the reader to assume the story to be a truth (Yule, 1985). The present research reveals that the writer has employed the linguistic device of presupposition very successfully in order to establish the issue of ethnicity. It aims at ensuring acceptance without questioning on the part of the reader. Following examples from the text of the novel under analysis are very important in this respect:

1) In Chapter Two, the writer has put up a reference of history book of an Iranian writer, Khorami, as a device of presupposition. He quotes this reference just to ensure the reader that the issue of exploitation of the Hazara has historical validity and thus need not be questioned.

2) There is a historical realism in The Kite Runner. There are various references of dates which create the impression of chronological accuracy. He describes the changing political games in Afghanistan. For instance, the era of King Zahir Shah, the Russian invasion in 1981, the Taliban's occupation in1996, the Taliban put ban on kite fighting in 1996 and, the massacre of Hazaras in 1998.

3) The writer tries to highlight the issue of ethnicity through the validity of the history when Amir says, "...History isn't easy to overcome. Neither is religion. In the end, I was a Pasthun and he was a Hazara, I was Sunni and he was Shi'a, and nothing was ever going to change that."

4) The writer shows blood superiority for Pashtuns and boss superiority for Hazaras in the following lines:

"Hassan and I fed from the same breasts. We took our first steps on the same lawn in the same yard. And, under the same roof, we spoke our first words. Mine was _Baba_. His was_Amir_.My name."

Amir says that the event that emerged in 1975, to which he referred in Chapter One, was 'already laid in those first words.'

"Looking back on it now, I think the foundation for what happened in the winter of 1975--and all that followed--was already laid in those first words." (Ch.2)

5) The novelist uses the linguistic device of flashback through which the narrator tells about events that have occurred in the past. He uses this technique of flashback to establish the validity of the story in many chapters of The Kite Runner.

\subsection{Sentence Level}

In the present research, Huckin's (1997) analytic tools for conducting critical analysis of the 
text have also been used to analyze the text of The Kite Runner, at the sentence level. It has been found that the writer has used the linguistic devices of Topicalization and presupposition in order to establish the issue of ethnicity.

\subsubsection{Topicalization}

The analysis of the text has revealed that the writer has certain specific objectives in putting particular information at the topic position of the sentence. He makes the reader realize the significance of certain pieces of information. The writer has employed this technique to establish the discourse of difference between Pashtuns and Hazaras. Following are notable examples from the text of the novel under analysis:

1) "Hey, you!" he said. "I know you."

2) "You! The Hazara! Look at me when I'm talking to you!"

3) Like Ali, she was a Shi'a Muslim and an ethnic Hazara.

4) "An entire chapter dedicated to Hassan's people! In it, I read that my people, the Pashtuns, had persecuted and oppressed the Hazaras."

5) Amir thought, "He was just a Hazara, wasn't he?" (Ch.7)

6) "He wrinkled his nose when he said the word Shi'a, like it was some kind of disease."

\subsubsection{Technique of presupposition}

The writer has used the device of presupposition at the sentence level by giving a reference to a book of history at the thematic level of the sentence in the novel, The Kite Runner. By using the device of presupposition, the writer floats the ideas in such a way as to be accepted without questioning. For this purpose, he gives a reference of the history book of Khoramian Iranian writer. Following are some of the examples from the text of the novel under analysis:

1) "The book said that my people had killed the Hazaras, driven them from their lands, burned their homes, and sold their women." (Ch.2)

2) "The book said part of the reason Pashtuns had oppressed the Hazaras was that Pashtuns were Sunni Muslims, while Hazaras were Shi'a.” (Ch.2)

3) "It also said some things I did know, like that people called Hazaras _mice-eating, flat-nosed, load-carrying donkeys_."(Ch.2)

\subsection{Words Level}

In the present research, Critical discourse analysis was also applied at the level of individual words. Certain words have been pointed out that carry certain connotations (Huckin, 1997). This type of analysis was conducted to reveal the text's level of formality or informality, and its degree of technicality, etc. The quantitative methodology of Corpus linguistics was used as a supplement to determine the frequencies of certain lexical items. It has been found that the writer has used the linguistic device of Metaphors, Register and First person narrative very 
effectively in his novel, The Kite Runner. He uses this technique to highlight the issue of ethnicity. Following are some of the examples from the novel under analysis:

\subsubsection{The use of Metaphor}

The use of metaphors is a very effective linguistic tool in descriptive writing. It is employed to create a vivid image and strong sensation in the reader's mind. It makes the text alive for the reader (Lakoff and Johnson, 1980). The present research reveals that the writer of the novel uses particular metaphors in order to influence the mind of the readers. Following are some of the examples from the text of the novel under analysis:

\subsubsection{The Metaphor of Lamb}

In The Kite Runner, the writer uses the metaphor of lamb in the most significant passages to influence the conceptual system of the reader. They have especially been used to describe the character and personality of Hassan. The reader associates many characteristics with Hassan who has been described as a lamb. The writer presents Hassan's comparison to the lamb just to highlight the themes of sacrifice, submission and oppression. In these references, the Hazara is a lamb and the Pashtun is a butcher. This is to establish exploitation of the Hazara by the Pashtun.

1) "Just before the mullah slaughtered the lamb, Amir saw its look of acceptance, as though it understood that its death was for "a higher purpose." Instead of standing up for Hassan the way his friend had for him so many times, he fled. Amir tried to convince himself that he ran out of fear, but he knew that he felt Hassan to be his sacrificial lamb, the one to suffer for him so that he could live happily."'(Ch. 2)

2) "He moved his head slightly and I caught a glimpse of his face. Saw the resignation in it. It was a look I had seen before. It was the look of the lamb." (Ch.7)

\subsubsection{The Metaphor of Kite}

The Metaphor of Kite is highly significant in the text of the novel, The Kite Runner. The kite tournament of 1975 is particularly significant regarding betrayal and redemption. During the tournament, Hassan gets raped while running his kite, while Amir commits the sin of betrayal and cowardice. Though Amir suffers from injuries and trials when he rescues Sohrab, kite running finally makes him feel redeemed in America. Thus, the Kite is a significant symbol with multiple layers of meanings.

\subsubsection{The Metaphor of River}

The Metaphor of River is also very significant in the text of the novel, The Kite Runner. The writer chooses this metaphor to describe America as a river. Amir says, "America was different. America was a river, roaring along, unmindful of the past. I could wade into this river, let my sins drown to the bottom, let the waters carry me someplace far."

\subsubsection{The Metaphor of Garbage}

The Metaphor of Garbage has also been used in the text of The Kite Runner. Assef and his 
companions do not consider the lives of Hazaras valuable. They do not treat them as human beings. Assef tells Amir, "Afghanistan is like a beautiful mansion littered with garbage, and someone has to take out the garbage." He even uses the term 'ethnic cleansing' for the removal of the Hazara from Afghanistan. The writer highlights hatred against Hazaras with this garbage metaphor. This metaphor also shows asymmetrical relationship between two ethnic groups, the Pashtun and the Hazara (Fairclough, 1992).

\subsubsection{The usage of a foreign language, Farsi}

The writer uses the Register of Farsi in The Kite Runner. By using this technique, he gives the vivid experience of the Afghan society to the reader. The use of Farsi words creates natural touch in conversation. It enhances informal level of the text (Huckin, 1997). For this purpose, the writer uses the following Farsi words with the frequency as mentioned in Table No. 3.1.

The writer uses words like 'Baba or Baba Jan' instead of 'dad' or 'father'. He also uses words such as "Inshallah" and "Naan". The reader understands these words by context.

Table No. 3.1. The frequency of the Farsi words

\begin{tabular}{|l|l|l|}
\hline Sr. No. & Farsi word & Frequency \\
\hline 1 & Baba & 12 \\
\hline 2 & Baba Jan & 18 \\
\hline 3 & Inshallah & 36 \\
\hline 4 & Naan & 29 \\
\hline
\end{tabular}

The table 3.1 shows the frequency of the Farsi words used in the Khaled Hosseini's novel, The Kite Runner. Corpus analysis toolkit AntConc 3. 2. $4 w$ was used for data analysis.

\subsubsection{First - person narration}

First person narrative means to express feelings from the "I" point of view. The writer describes most of the events from the narrator's point of view. The narrator is one of the characters in the novel. There is frequent use of the pronouns $I$ and $m e$. This technique makes the reader perceive the point of view, opinions, thoughts, and feelings only of the narrator. The first-person narrator of The Kite Runner, Amir, reveals his identity in the first sentence of the novel:

"I became what I am today at the age of twelve, on a frigid overcast day in the winter of 1975. I remember the precise moment, crouching behind a crumbling mud wall, peeking into the alley near the frozen creek."(Ch.1)

The writer uses first person pronouns like I, me, and my frequently in The Kite Runner. Their frequency has been mentioned in Table No. 3.2. 
Table No. 3.2. The frequency of the first person pronouns

\begin{tabular}{|l|l|}
\hline Person & Frequency \\
\hline I & 4184 \\
\hline Me & 945 \\
\hline My & 1031 \\
\hline We & 286 \\
\hline
\end{tabular}

The table 3.2 shows the frequency of the first person pronouns used in the Khaled Hosseini's novel, The Kite Runner. Corpus analysis toolkit AntConc 3. 2. $4 \mathrm{w}$ was used for data analysis.

\section{Conclusion}

The objective of the present study was to identify the role of the linguistic devices in representing ethnicity in The Kite Runner. The detailed analysis of the text, both at the macro level and the micro level, reveals that specific Linguistic Devices have played a significant role in representing ethnicity in the novel. The writer has used the linguistic devices of foregrounding, backgrounding, presupposition and omission to frame the contents of the text for his objective. These linguistic devices proved very influential instrument to touch the cognitive structure of the reader. By way of a subtle manipulation of language, the writer successfully wields great influence on the preconceptions, beliefs, and ideologies of the readers. He intends to make the people accept false claims as true facts, or even to support plans contrary to their ideology. The writer has manipulated the text for the representation of ethnicity to materialize his political objectives. Thus, linguistic devices are powerful instruments for those who are interested in controlling the ideas of the people.

\section{References}

Edwards, J. (2009). Expatriate literature and the problem of contested representation: the case of Khaled Hosseini's the kite runner. Retrieved December 12, 2011, from http://www.inter-disciplinary.net/ati/diversity/multiculturalism/mcb2/edwards\%20paper.pdf

Fairclough, N. ( 1992). Discourse and social change. London: Polity Press.

Fairclough, N. (1995a). Critical discourse analysis. London: Longman.

Fairclough, N. (1995b). Media discourse. London: Arnold.

Guerin, B. (2007). Two 'linguistic devices' that require social context: Integrating social and linguistic analysis. Retrieved April 16, 2012, from http://www.nzlingsoc.org/documents/Guerin\%20devices.pdf 
Hosseini, K. (2003). The kite runner. New York: Riverhead Books.

Huckin, T. N. (1997). Critical discourse analysis. Retrieved August 04, 2011, from http://eca.state.gov/education/engteaching/pubs/BR/functionalsec3_6.htm

Lakoff, G., \& Johnson, M. (1980). Metaphors we live by. Chicago: Chicago University Press.

Lidyawati, S. (2010). An analysis of main characters in Khalid Hossein's novel: The kite runner. Retrieved January 05, 2012, from http://repository.usu.ac.id/bitstream/123456789/13424/1/10E01043.pdf

Luckhardt, J. K. (2010). Building cultural competence through multicultural fiction. $\begin{array}{llll}\text { Retrieved Jan } & \text { 12, 2012, from }\end{array}$ http://thescholarship.ecu.edu/bitstream/handle/10342/2832/Luckhardt_ecu_0600M_10140.pd $\mathrm{f}$

Mautner, G. H. (1995). 'Only Connect. 'Critical Discourse Analysis and Corpus Linguistics. Retrieved August 05, 2011, from http://citeseerx.ist.psu.edu/viewdoc/download?doi=10.1.1.116.7633\&rep=rep1\&type=pdf

McGregor, S. L. (2003). Critical Discourse Analysis--A Primer. Retrieved December 12, 2011, from http://www.kon.org/archives/forum/15-1/mcgregorcda.html

Van Dijk, T. (2005). Discourse analysis as ideology analysis. In C. \&. Schaffner, Language and peace (pp. 17-33). Amsterdam: Harwood academic publishers.

Van Dijk, T. ( 2006). Discourse and manipulation. Discourse and society, 17, 359-383. Retrieved March 2012, from http://www.discourses.org/OldArticles/Discourse\%20and\%20manipulation.pdf

Wodak, R. (2001). What CDA is about - a summary of its history, important concepts, and its development. In R. Wodak, \& M. Meyers, Methods of CDA. (pp. 1-13). London: Sage Publications.

Wodak, R. (2003). The genesis of racist discourse in Austria since 1989. In C. R. Coulthard, Text and practices (pp. 107-128). London \& New York: Routledge.

Wodak, R. (2006). Critical linguistics and critical discourse analysis. In J. Verschueren, \& J. O. Ostman, Handbook of pragmatics. Amsterdam: John Benjamins.

Yule, G. (1985). The study of language. Cambridge: Cambridge University Press.

Zhao, J. (2011). Comparative critical analysis of discourse structures. Retrieved May 10, 2012, from http://ojs.academypublisher.com/index.php/tpls/article/view/3767/0

\section{Copyright Disclaimer}

Copyright reserved by the author(s).

This article is an open-access article distributed under the terms and conditions of the Creative Commons Attribution license (http://creativecommons.org/licenses/by/3.0/). 